IBIMA Publishing

Journal of Innovation Management in Small \& Medium Enterprises

https://ibimapublishing.com/articles/JIMSME/2021/238722/

Vol. 2021 (2021), Article ID 238722, 11 pages, ISSN: 2166-076X

DOI: $10.5171 / 2021.238722$

Research Article

\title{
SMEs and Innovation in The European Context
}

\section{Diana Anamaria HERTE ${ }^{1}$, Dragos DIANU ${ }^{2}$, Monica CIUCOS $^{3}$ Daniel BADULESCU ${ }^{4}$ and Alina BADULESCU ${ }^{5}$}

\author{
${ }^{1}$ Doctoral School of Economics Sciences, Faculty of Economic Sciences, University of Oradea \& \\ "Partenie Cosma" High-School, Oradea, Romania \\ 2,3,4,5,6 Department of Economics and Business, and Doctoral School of Economic Sciences, Faculty of \\ Economic Sciences, University of Oradea, Oradea, Romania
}

Correspondence should be addressed to: Dragos DIANU; dianu.dragos21@gmail.com

Received date: 18 March 2021; Accepted date: 23 June 2021; Published date: 2 August 2021

Academic Editor: Laurentiu-Stelian Mihai

Copyright (C) 2021. Diana Anamaria HERTE, Dragos DIANU, Monica CIUCOS, Daniel BADULESCU and Alina BADULESCU. Distributed under Creative Commons Attribution 4.0 International CC-BY 4.0

\begin{abstract}
Innovation is a key driver in enhancing competitiveness of firms and fostering employment and job creation. This is the reason for the existence of a growing body of literature regarding how firms can improve their innovative practice and, more recently, how they can benefit from the advantages of digitisation. Moreover, many related statistical data is available for big companies, but the topic is relatively little addressed in the case of SMEs. This is much surprising given the large number of SMEs and how they strive to successfully compete with big companies in a more and more competitive business environment. Consequently, our article comes to fill this gap and provide insights on the status of European and Romanian SMEs in terms of innovation and digitisation and their impact on the overall competitiveness. Relevant conclusions and directions for further actions can be retrieved and recommended for the future.
\end{abstract}

Keywords : Entrepreneurship ; innovation ; SMEs ; performance ; EU ; Romania.

\section{Introduction}

Setting up, growth and strengthening of firms are an intensely debated topic in the economic literature. The growth of firms is associated with innovation and technological change, and the contemporary period has abundantly demonstrated that the firms' survival and growth occurs not only because of

Cite this Article as: Diana Anamaria HERTE, Dragos DIANU, Monica CIUCOS Daniel BADULESCU and Alina BADULESCU (2021), "SMEs and Innovation in The European Context", Journal of Innovation Management in Small and Medium Enterprise, Vol. 2021 (2021), Article ID 238722, DOI: 10.5171/2021.238722 
quantitative accumulations, but rather as a result of the incorporation of new technologies, an open attitude towards innovation, whether it is technical, managerial, or commercial. There is a lot of statistical information regarding the structure and evolution of SMEs sector, but it is surprisingly poor in terms of start-ups, despite abundant political rhetoric. In this article we aim to approach the main features of small and medium enterprises in relation to innovation, competitiveness, and digitalization, using key outcome data in supporting competitiveness and innovation among these firms, involvement in the introduction of new products, processes and techniques, in e-commerce and digitalization, at the level of the European Union (EU) and of a member state, Romania, respectively.

\section{Literature Review}

The literature regarding the place of SMEs in economy and society, the value of private initiative, the intention to set up new businesses, to encourage launching of new firms, is rich and diverse. The expansion of the SME sector is expected to lead to economic growth, prosperity, a successful business environment, awareness of the public administration to the SMEs needs (Rad (Herte), 2020). As a consequence, the financial and nonfinancial support measures, will accelerate and strengthen this process (Bădulescu and Petria, 2011).

Undoubtedly, the SME sector must be supported, that setting up of new firms, especially in innovative dynamic sectors, benefiting from the experience and ideas of capable people, must be encouraged, but we have to ask ourselves what kind of measures should be taken, what is their degree of selectivity and what indicators can best display the effects of these measures and their mutual relations? Audretsch and Lehman (2005) found that there is a positive impact on the growth and strengthen of firms when these firms invest in research and development, and Thornhill (2006) argues that the level of innovation in a firm is positively correlated with its performance, measured by growth turnover, even if the characteristics underlying the success of innovations are very unevenly space distributed (Rodríguez-Pose, 2010). The evolution of the number of (existing) enterprises and new entrants determines the concentration and competitiveness of the market (Audretsch and Mata, 1995). Once a firm enters the market, a selection process takes place (Jovanovic, 1982), through which the less efficient firms decrease in size and disappear, and the most efficient ones survive and grow.

The literature also shows that the accessibility of firms to financing and innovation sources, together with the quality and quantity of human capital or proximity to scientific and technological infrastructures, are among the most important features that shape the behaviour of small entrepreneurial firms, their performance and innovative climate (Feldman and Audretsch, 1999), (Andersson and Noseleit, 2011), (Gompers, et al., 2010). Moreover, the role of innovation and stimulating competitiveness in SMEs, start-ups, clusters and growth poles, are found in several studies and contributions, related to the innovation and knowledge regions (Saxenien, 1994), (Audretsch and Lehmann, 2005), the determinants of competitive advantage in firms and nations (Porter, 1990), but also in the competitiveness strategies that guide the European Union after the year 2000 - The Lisbon Strategy, or Europe 2020 (European Parliament, 2010), (European Commission, 2010).

Innovations have (direct and indirect) positive effects not only on the company who creates and promotes them, but also in the national economy. However, despite the simplicity of this statement and the many empirical evidence, the association between entrepreneurship, small firms and innovation is difficult to describe. Researchers and policy makers often have difficulty introducing them into strong theoretical models to substantiate viable policy programs (Badulescu and Cadar, 2016). 
Nevertheless, there are also considerations and criticisms that temper this enthusiasm, arguing that launching dynamic, entrepreneurial firms cannot be done by anyone, that entrepreneurs face a substantial risk of failure, and that most new entrants are far from the profile of the experienced entrepreneur, with a good social capital, with reasonable resources, motivated by the implementation of an idea or an innovation (Kritikos, 2014). Shane (2008) proposes to focus government resources not on stimulating the setting up of new firms, but on existing young firms, with growth potential, in cutting-edge, innovative areas that can ensure economic growth, revenue and training effects, and, especially, skilled and stable jobs. Haltiwanger et al. (2007) or Kok et al. (2007) show that the productivity of the firm increases with the age of the firm, it reaches a maximum value and then has a slightly decreasing trend, so a new firm, on average, will use resources less efficiently than an existing one. An OECD report from 2008 showed that decision-makers should not only encourage the creation of new businesses, because, at the same time, other businesses are declining or disappearing (Ahmad and Seymour, 2008). A high level of self-employment, or firms with 1 or 2 employees, with small contributions to employment, innovation, efficiency and complex productive investments, is not necessarily a good indicator of dynamic and innovationoriented entrepreneurial activity (Ahmad and Seymour, 2008), (Badulescu, 2013). In other words, firms are strong when they have employees, through which they grow, can compete in the market and are willing to innovate and develop (Audretsch and Thurik, 2001). Growing and consolidating successful and sustainable entities, and creating a competitive business environment that stimulates the growth of productive and innovative firms should be the main goal of economic policies for small and medium-sized businesses (Rad (Herte), 2020).

\author{
Main results and trends in the field of \\ supporting SMEs' competitiveness and \\ innovation during $2009-2018$, in the \\ European Union
}

According to the latest data, in 2018, the overall performance at EU level of all 28 Member States in terms of supporting competitiveness and innovation for SMEs reached an average performance score of 0.464 measured on a scale where 0 represents "the worst" and +1 "the best" result. This performance result places the "Skills and Innovation" principle among the areas with the lowest performance, and in which EU policies for SME have had the least effect. The negative picture of performance is confirmed when looking at the compound annual growth recorded in the period 2009-2018 (European Commission, 2019a).

The introduction of innovative business practices is not a common practice for most SMEs. In Table 1 below we present the evolution of 4 key indicators of innovation in SMEs (taken from the European Innovation Scoreboard - EIS Database, 2019). Thus, just over a quarter of SMEs have introduced new products or production processes (which are not / have not been developed by other firms, or significantly improved in the last 10 years). SMEs seem to have a slightly better result in introducing innovations in marketing techniques and organizational development (between 33\% and 40\%). The innovations developed internally by small and medium-sized firms (in-house) follow a slightly downward curve, in the period 2009-2018, amounting to somewhere between $31.6 \%$ and $28.1 \%$. Finally, Innovative SMEs collaborating with others has the lowest values among the analysed indicators and probably the fastest decrease, especially in the last years of the interval (Rad (Herte), 2020). 
Table 1: Key results in supporting competitiveness and innovation (\% of total SMEs)

\begin{tabular}{|l|l|l|l|l|l|l|l|l|l|l|l|}
\hline & $\mathbf{2 0 0 9}$ & $\mathbf{2 0 1 0}$ & $\mathbf{2 0 1 1}$ & $\mathbf{2 0 1 2}$ & $\mathbf{2 0 1 3}$ & $\mathbf{2 0 1 4}$ & $\mathbf{2 0 1 5}$ & $\mathbf{2 0 1 6}$ & $\mathbf{2 0 1 7}$ & $\mathbf{2 0 1 8}$ & $\begin{array}{l}\mathbf{2 0 1 8} \\
\mathbf{2 0 1 1}\end{array}$ \\
\hline $\begin{array}{l}\text { SMEs } \\
\text { product or } \\
\text { process } \\
\text { innovations }\end{array}$ & 35,1 & 33,5 & 33,5 & 30,6 & 30,6 & 30,9 & 30,9 & 34,3 & 28,3 & 32,6 & 84,5 \\
\hline $\begin{array}{l}\text { SMEs } \\
\text { introducing } \\
\text { marketing } \\
\text { or } \\
\text { organisation } \\
\text { al } \\
\text { innovations }\end{array}$ & 39,9 & 39,8 & 39,8 & 36,2 & 36,2 & 34,9 & 34,9 & 35,6 & 32,9 & 33,9 & 82,7 \\
\hline $\begin{array}{l}\text { SMEs } \\
\text { innovating } \\
\text { "in-house" }\end{array}$ & 30,2 & 31,6 & 31,6 & 28,7 & 28,7 & 28,8 & 28,8 & 28,1 & 29,1 & 28,1 & 92,0 \\
\hline $\begin{array}{l}\text { Innovative } \\
\text { SMEs } \\
\text { collaboratin } \\
\text { g whers with } \\
\text { others }\end{array}$ & 11,2 & 8,9 & 8,9 & 10,3 & 10,3 & 11,2 & 11,2 & 11,8 & 7,0 & & \\
\hline
\end{tabular}

Source: European Commission (2019a), European Innovation Scoreboard Database,

The share of online sales in the overall turnover of all enterprises hardly exceeds $10 \%$ of the total (on average), and also the involvement of SMEs in e-commerce is relatively modest, although growing in the last decade. Better figures are found when purchasing goods or services online (Table 2).

Table 2: Participation of SMEs in e-commerce in the EU (2009-2019, \% of total firms)

\begin{tabular}{|l|l|l|l|l|l|l|l|l|l|l|l|}
\hline & $\mathbf{2 0 0 9}$ & $\mathbf{2 0 1 0}$ & $\mathbf{2 0 1 1}$ & $\mathbf{2 0 1 2}$ & $\mathbf{2 0 1 3}$ & $\mathbf{2 0 1 4}$ & $\mathbf{2 0 1 5}$ & $\mathbf{2 0 1 6}$ & $\mathbf{2 0 1 7}$ & $\mathbf{2 0 1 8}$ & $\mathbf{2 0 1 9}$ \\
\hline $\begin{array}{l}\text { SMEs selling } \\
\text { online * }\end{array}$ & 11 & 13 & 12 & 13 & 14 & 15 & 16 & 17 & 17 & 17 & 18 \\
\hline $\begin{array}{l}\text { Share of } \\
\text { enterprises' } \\
\text { turnover on } \\
\text { e-commerce } \\
\text { (\%) }\end{array}$ & 7 & 8 & 8 & 8 & 8 & 8 & 9 & 9 & 10 & 10 & 11 \\
\hline $\begin{array}{l}\text { Enterprises } \\
\text { having } \\
\text { received } \\
\text { orders } \\
\text { online* }\end{array}$ & 11 & 13 & 12 & 13 & 14 & 15 & 16 & 17 & 17 & 17 & 18 \\
\hline
\end{tabular}

Notes: firms with 10-250 employees, without the financial sector; * (at least $1 \%$ of the turnover) Source: Eurostat, Database. ICT usage in enterprises (2019)

The negative change in the performance of innovation in the EU in 2019 compared to 2014 is largely associated with the difficult involvement of SMEs in innovation activities, registering a major decrease in the share of SMEs collaborating with other firms (-3.8\% compared to 2014), which introduce marketing or organizational innovations, and which innovate in house ($1 \%$, each). The $1.7 \%$ increase for SMEs 
introducing an innovative product or process is not enough to offset the overall decline in performance and interest in innovation among SMEs in the European Union (European Commission, 2019a).

The Innobarometer 2015 on Innovation trends at EU enterprises (FB 415) provides a suggestive picture of innovation trends in EU enterprises (European Commission, 2015) on the dynamics of innovation activities within different SME sub-groups, as well as a comparison to the performance of large firms. Although the share of innovative companies in all types of companies has increased since 2014, and currently almost $72 \%$ of them have introduced at least one innovation in recent years, this result is mostly based on the innovation activities of large companies: $95 \%$ of companies with more than 250 employees did so, compared to $70 \%$ of those with 1-9 employees (Table 3). The same pattern is observed in relation to the areas in which companies innovate. For example, $41 \%$ of companies with 1-9 employees introduced new goods, compared to $72 \%$ for companies with more than 250 employees. Moreover, only 29\% of micro-enterprises have introduced new or significantly improved processes compared to $75 \%$ of large companies. Medium-sized enterprises report that they have introduced new or significantly improved marketing strategies (50\%), compared to micro-enterprises (34\%) or large firms (40\%) (European Commission, 2015).

Table 3: Has your company introduced any of the following types of innovation in recent years? (new or significantly improved products / services / processes / strategies)

\begin{tabular}{|c|c|c|c|c|c|c|}
\hline \multirow[b]{2}{*}{ Innovation type } & \multirow[b]{2}{*}{ Response } & \multirow{2}{*}{$\begin{array}{l}\text { Total } \\
\text { EU28 }\end{array}$} & \multicolumn{4}{|c|}{ Company size (no. employees) } \\
\hline & & & 1-9 & $10-49$ & $50-249$ & $250+$ \\
\hline \multirow[b]{3}{*}{ Goods } & Yes & $42 \%$ & $41 \%$ & $46 \%$ & $53 \%$ & $72 \%$ \\
\hline & No & $57 \%$ & $58 \%$ & $53 \%$ & $44 \%$ & $26 \%$ \\
\hline & $\mathrm{N} / \mathrm{A}$ & $1 \%$ & $1 \%$ & $1 \%$ & $3 \%$ & $2 \%$ \\
\hline \multirow[b]{3}{*}{ Services } & Yes & $45 \%$ & $45 \%$ & $45 \%$ & $52 \%$ & $65 \%$ \\
\hline & No & $54 \%$ & $55 \%$ & $55 \%$ & $46 \%$ & $33 \%$ \\
\hline & $\mathrm{N} / \mathrm{A}$ & $1 \%$ & $0 \%$ & - & $2 \%$ & $2 \%$ \\
\hline \multirow[b]{3}{*}{ Processes } & Yes & $32 \%$ & $29 \%$ & $43 \%$ & $56 \%$ & $75 \%$ \\
\hline & No & $67 \%$ & $71 \%$ & $56 \%$ & $43 \%$ & $24 \%$ \\
\hline & $\mathrm{N} / \mathrm{A}$ & $1 \%$ & - & $1 \%$ & $1 \%$ & $1 \%$ \\
\hline \multirow{3}{*}{$\begin{array}{l}\text { Marketing } \\
\text { strategies or } \\
\text { organisational } \\
\text { methods }\end{array}$} & Yes & $36 \%$ & $34 \%$ & $39 \%$ & $50 \%$ & $40 \%$ \\
\hline & No & $64 \%$ & $65 \%$ & $61 \%$ & $49 \%$ & $58 \%$ \\
\hline & $\mathrm{N} / \mathrm{A}$ & $0 \%$ & $1 \%$ & $0 \%$ & $1 \%$ & $2 \%$ \\
\hline
\end{tabular}

Source: European Commission, Innobarometer 2015 on the Innovation trends at EU enterprises (2015)

However, SMEs positively assess the contribution of innovation to their financial performance (Table 4), so $4 \%$ of large firms reported that at least $25 \%$ of turnover came from innovative goods or services, compared to $15-19 \%$ in the case of SMEs. The willingness of companies to make some investments in innovation also varies depending on their size. Micro-enterprises (with 29\% responses) are the least inclined to invest part of their turnover in research and development, compared to $67 \%$ for large firms (European Commission, 2015). This observation shows that, especially for micro-enterprises, innovation is still quite difficult, and it is still hard to find its rightful place in the business logic and development strategies of these companies. 
Table 4: What percentage (approximately) of your company's turnover was due to innovative goods or services introduced in the last two years?

\begin{tabular}{|l|l|c|c|c|c|}
\hline Percentage of turnover & \multirow{2}{*}{ Total EU28 } & \multicolumn{3}{|c|}{ Company size (no. employees) } \\
\cline { 3 - 5 } & & $\mathbf{1 - 9}$ & $\mathbf{1 0 - 4 9}$ & $\mathbf{5 0 - 2 4 9}$ & $\mathbf{2 5 0 +}$ \\
\hline None (\%) & $9 \%$ & $10 \%$ & $6 \%$ & $5 \%$ & $6 \%$ \\
\hline Between 1 and 5\% & $22 \%$ & $22 \%$ & $19 \%$ & $21 \%$ & $15 \%$ \\
\hline Between 6 and 10\% & $21 \%$ & $21 \%$ & $21 \%$ & $22 \%$ & $32 \%$ \\
\hline Between 11 and 25\% & $20 \%$ & $19 \%$ & $26 \%$ & $20 \%$ & $26 \%$ \\
\hline Between 26 and 50\% & $9 \%$ & $10 \%$ & $8 \%$ & $8 \%$ & $2 \%$ \\
\hline 51\% or more & $9 \%$ & $9 \%$ & $7 \%$ & $9 \%$ & $2 \%$ \\
\hline N/A & $10 \%$ & $9 \%$ & $13 \%$ & $15 \%$ & $17 \%$ \\
\hline
\end{tabular}

Source: European Commission, Innobarometer 2015 on the Innovation trends at EU enterprises (2015)

Investing in innovation does not seem to be part of SMEs' business development plans, only $36 \%$ of them have invested between 1 and 5\% of 2014 turnover in innovation activities. Although the figure above seems, at first glance, encouraging, we must see the $40 \%$ companies that have not invested anything or almost nothing (less than 1\%) of their turnover. This weak orientation towards investment in innovation is more common in small and micro enterprises compared to medium and large ones $(24 \%$ compared to 8\%). Moreover, young companies, less than 5 years old, report low investments in innovation, almost half compared to those over 5-6 years old (European Economic and Social Committee, 2017). Investing in innovation is not a priority in the future plans of SMEs either. Companies with less than 50 employees that have introduced at least one innovation in the last 2 years, say they do not intend to invest in innovation in the next year $(12 \%-17 \%$, vs. $5 \%-7 \%$ for enterprises with more than 50 employees).

It is therefore confirmed that the negative results of the EU's innovation performance are largely associated with the decline in SME participation in innovation activities. The pressing difficulties and problems of survival and consolidation make them seriously diminish the value of innovation activities.

\section{Romania: Competitiveness and innovation in SMEs}

At the end of 2018, almost 486,000 SMEs were registered in Romania, representing about $99.7 \%$ of the total companies, of which $88.4 \%$ were micro-enterprises, $9.5 \%$ were small enterprises and $1.8 \%$ were medium-sized enterprises. The Romanian SME sector generated approximately $66 \%$ of employment in the private sector, slightly below the EU average $(66.6 \%)$ and contributed about $53 \%$ to the economic value-added created, although this contribution was about $3.7 \%$ below the EU average in 2018 (European Commission, 2019b).

According to the European Innovation Scoreboard (EIS), Romania is ranked as a modest innovator, and innovation performance has deteriorated from $50 \%$ of the EU average in 2008 to $34 \%$ in 2019 (European Commission, 2017, 2020a). Finally, Romania is poorly represented in the category of innovative enterprises oriented towards sustained growth, following the EU average, which also does not have outstanding performance, compared to dynamic regions of the world (USA, Southeast Asia, etc.). The Word Economic Forum Report for 2019 places Romania on the 51st place out of 141 countries included in The Global Competitiveness Report, with a score of 64.4 points out of 100 , slightly better than the previous edition of the report (53rd place in the world) and classified it in the category of efficiency-based economies. Its strengths include: stable macroeconomic environment, market size, technological 
training and education at all levels (World Economic Forum, 2019).

Romania's performance in the field of skills and innovation remains among the weakest in the EU. According to EIS (2020a), after a constant and strong decline between 2008 and 2014, Romania's performance stabilized between 2014 and 2016 and slightly increased in 2017 and 2019. Among the dimensions of innovation Innovation-friendly environment \& Sales impacts are the strongest innovative dimensions, and Broadband penetration \& Medium and high-tech product exports are the only two indicators that approach the EU's average performance. In contrast, Innovators, Investments in innovations, and Human Resources are the weakest dimensions of innovation. Extremely low scores are also for Participating in lifelong learning, SMEs with product or process innovations, SMEs with marketing or organizational innovations, or SMEs innovating in-house.

In the category of high-growth innovative enterprises, Romania also lags behind the EU average. In 2019, employment in these enterprises accounted for only $2.8 \%$ of total jobs in Romania (compared to the EU average of $4.8 \%$ ), ranked 24th in the EU (European Commission, 2020b), (European Commission, 2017).

In summary, Romania has the largest positive difference from the $\mathrm{EU}$ in the growth rate of GDP, the pace of business creation and TEA (Total Early-stage Entrepreneurial Activity) and the largest negative difference in research and development expenditures of major firms reported to GDP / capita and government procurement of advanced technology products (European Commission, 2020a).

\section{Romania: Current situation and further prospects of start-ups in terms of innovation and digitalization}

Regarding the situation of start-ups in Romania regarding innovation, the picture is more complicated and less systematic, sometimes contradictory (Rad (Herte), 2020). For example, the 2019 Ernst \& Young study does not dedicate a separate chapter to Romanian start-ups, although elements of innovation can be found in other sections of the report (Ernst \& Young Global Limited, 2019). Somewhat similarly, a study done by the National Council of Small and Medium Private Enterprises in Romania (CNIPMMR) reveals that more than half of the analysed companies have a low level of digitalization (between 0 and 30\%) (CNIPMMR, 2019). Under these conditions, the discussion on the orientation towards innovation and digital skills of Romanian start-ups becomes either marginal or must be directed to certain sectors (high-tech, knowledge intensive business services) and excluded from the area of the entire population of SMEs and start-ups, respectively.

The 2014 Global Entrepreneurship Monitor (GEM) report for Romania reveals that the percentage of entrepreneurs with products or services they consider unique and unknown to their customers has increased in recent years (Dézsi-Benyovszki, et al., 2014, p. 25), and Early stage entrepreneurs (understanded here with start-up entrepreneurs) are somewhat more innovative than Established business owner-managers (EB) (Table 5), although, in the case of $\mathrm{EB}$, competitive uniqueness has slightly increased in recent years of the study (Dézsi-Benyovszki, et al., 2014). The value of this information is obvious, but the lack of more recent editions on entrepreneurship in Romania of GEM may diminish their usefulness and timeliness. 
Table 5: Product novelty of entrepreneurs' businesses in Romania, 2011-2014 (\%)

\begin{tabular}{|l|c|c|c|c|c|c|c|c|}
\hline & \multicolumn{6}{|c|}{ Established entrepreneurs } & \multicolumn{3}{c|}{ Early-stage entrepreneurs } \\
\hline Years & $\mathbf{2 0 1 1}$ & $\mathbf{2 0 1 2}$ & $\mathbf{2 0 1 3}$ & $\mathbf{2 0 1 4}$ & $\mathbf{2 0 1 1}$ & $\mathbf{2 0 1 2}$ & $\mathbf{2 0 1 3}$ & $\mathbf{2 0 1 4}$ \\
\hline $\begin{array}{l}\text { Product new to } \\
\text { all customers }\end{array}$ & $5 \%$ & $17 \%$ & $15 \%$ & $9 \%$ & $9 \%$ & $13 \%$ & $14 \%$ & $13 \%$ \\
\hline $\begin{array}{l}\text { Product new to } \\
\text { some customers }\end{array}$ & $27 \%$ & $31 \%$ & $26 \%$ & $21 \%$ & $34 \%$ & $35 \%$ & $33 \%$ & $24 \%$ \\
\hline $\begin{array}{l}\text { Product new to } \\
\text { none of the } \\
\text { customers }\end{array}$ & $67 \%$ & $52 \%$ & $59 \%$ & $71 \%$ & $57 \%$ & $52 \%$ & $53 \%$ & $63 \%$ \\
\hline
\end{tabular}

Source: adapted from Dézsi-Benyovszki et al, Entrepreneurship in Romania. Country Report (2014)

Finally, the Central and Eastern Europe Private Business Survey 2019 conducted by PwC considers companies that see digital transformation as a key to unlocking the next stage of growth and acting for its correct implementation, have a chance to grow faster and take advantage of changes in the economic environment ( $\mathrm{PwC}, 2019)$. Somewhat surprising compared to the previous findings, but probably a confirmation that the Romanian private sector is developing, in terms of digitalization and innovation, with two different speeds, the PwC study considers that Romanian entrepreneurs are more determined and advanced in using more essential technologies compared to other countries analysed in Central and Eastern Europe (CEE). Within the so-called 8 essential technologies in the field of digitalization, Romania ranked first on the list in 6 of them, namely: Artificial Intelligence, Augmented Reality, Blockchain, Drones, Virtual Reality, and 3D printing, and on one of the 3-4 places at IoT (Internet of Things) and Robotics.

This relatively high use of essential digital technologies in Romania may reflect the emergence of a vibrant technological ecosystem of start-ups, accelerators and funding hubs, undoubtedly stimulated by the low personal income tax rate for software developers. However, the $\mathrm{PwC}$ Report points out that this is not the case for all economies analysed (CEE): although SMEs in this area see, for example, robotics and IoT as highly relevant to their business, quite a few firms actually use them ( $\mathrm{PwC}$, 2019).

\section{Conclusions}

The literature and decision makers use many arguments that young entrepreneurial businesses stimulate economic growth by introducing innovative technologies, products and services, accelerate competition and make existing firms more competitive, increase the productivity of firms and economies and drive structural change. For this reason, knowing and enhancing the role of entrepreneurship, setting up new firms, stimulating the performance of existing firms, and especially of firms oriented towards sustained growth, in high-tech or knowledge intensive areas are therefore particularly important (Hatos et al., 2015). In the case of Romania, an EU member state analysed in this paper, there are several weaknesses and underperformances compared to EU standards and averages in terms of innovation and skills. Although Romania performs well regarding entrepreneurial intentions, business growth expectations and key technologies in the field of digitalization, Romania has a mediocre rate of setting up and survival of new businesses, and new firms do not have a significant effect on employment. The Romanian economy, overall, has low achievements in innovation and generation of advanced skills. The SMEs sector is affected by this low performance, and, in turn, impact the low performance in competitiveness and innovation in the economy and society as a whole. Insufficient public funding for education and research is only part of the problem, as long as many Romanian firms perceive 
investment in research and development as an expense, allot insignificant resources for innovation, digitalization and labour qualification. At the societal level, the willingness to digitize and online interactions with public administration, the business sector and, an exercise of innovation is reduced, changes are slow and sometimes superficial. Despite all these unfavourable situations and premises, there are also signs of positive change - the increase in the share of educated labour, especially in high-tech fields, the share of exports of high-tech products, the importance of firms oriented to sustained growth in innovative sectors. We can therefore see that the picture is particularly complex, and evidence of progress in entrepreneurship, start-ups and new firms shows a limited impact of reforms and measures taken, and unexploited potential, which is about to dissipate. The public administration, together with stakeholders, business associations, academics, must mobilize and review those ineffective policies that hinder the growth of SMEs and present new SME-friendly policies and tools to support the innovation-based SME sub-sectors in high-tech industries and knowledge-intensive services. Measures that go beyond the strictly economic framework should encourage a modern entrepreneurial mindset, more willingness to accept risk, avoiding to blame failure and open new generations to modern trends in the economy and society, to give a greater role to private initiative, education and innovation.

\section{Acknowledgments}

This paper received financial support through the project "SmartDoct - High quality programs for doctoral students and postdoctoral researchers of the University of Oradea to increase the relevance of research and innovation in the context of regional economy", ID / Project code: 123008, co-financed by the European Social Fund through the Human Capital Operational Program 2014-2020.

\section{References}

- Ahmad, N. and Seymour, R. (2008), Defining Entrepreneurial Activity: Definitions Supporting Frameworks for Data Collection 2008, OECD Statistics Working Paper, Paris.

- Andersson, M. and Noseleit, F. (2011), 'Start-ups and employment dynamics within and across sectors', Small Business Economics, $36 \quad$ (4), 461-483, http://www.jstor.org/stable/41486108.

- Audretsch, D. and Lehmann, E. (2005), 'Does the Knowledge Spillover Theory of Entrepreneurship Hold for Regions?', Research Policy, 34 (8), 1191-1202.

- $\quad$ Audretsch, D. and Mata, J. (1995), 'The Post-Entry Performance of Firms: Introduction', International Journal of Industrial Organization, 13, 413-419.

- Audretsch, D. and Thurik, R., 2001. Linking Entrepreneurship to Growth, OECD Science, Technology and Industry Working Papers, 2001/2, OECD Publishing, Paris.

- $\quad$ Badulescu, D. (2013), Dezvoltarea și finanțarea afacerilor antreprenoriale. Particularități în turism/Development and financing of entrepreneurial business. Particularities in tourism, Presa Universitară Clujeană, Cluj Napoca, Romania.

- Badulescu, D. and Cadar, O. (2016), 'Romania: Many Entrepreneurs but Few Innovators', The Annals of the University of Oradea. Economic Sciences, XXV (1), 465475.

- Badulescu, D. and Petria, N. (2011), 'Collateral's Importance in SMEs Financing: What Is The Banks' Response? Some Evidence For Romania', The Annals of the University of Oradea. Economic Sciences, XX (1), 256-260.

- CNIPMMR (2019). Profilul antreprenorului Start-Up Nation/ The entrepreeur's profile in the Start-Up Nation (Programme). [Online] [Retrieved February 17, 2021],

http://cnipmmr.ro/2019/05/15/profilulantreprenorului-start-up-nation/.

- Dézsi-Benyovszki, A., Nagy, A. and Szabó, T. (2014), Entrepreneurship in Romania. Country Report 2014, Global Entrepreneurship Monitor.

- $\quad$ Ernst \& Young Global Limited (2019), Barometrul afacerilor de tip startup din

Diana Anamaria HERTE, Dragos DIANU, Monica CIUCOS Daniel BADULESCU and Alina BADULESCU, Journal of Innovation Management in Small \& Medium Enterprises, DOI: 10.5171/2021.238722 
România/ The Romanian Startup business barometer. EY Romania.

- European Commission (2010), EUROPE 2020 A strategy for smart, sustainable and inclusive growth. [Online], [Retrieved February 12, 2021], https://ec.europa.eu/eu2020/pdf/COMPL ET\%20EN\%20BARROSO\%20\%20\%20007 \%20-\%20Europe $\% 202020 \% 20$ \%20EN\%20version.pdf.

- European Commission (2015), Innobarometer 2015 on the Innovation trends at EU enterprises. FB 415, European Commission, Directorate-General for Internal Market, Industry, Entrepreneurship and SMEs.

- $\quad$ European Commission (2017), Specific Support to Romania - Starts-ups, Scale-ups and Entrepreneurship in Romania, Luxembourg: E.C. Directorate-General for Research and Innovation, Publications Office of the European Union.

- European Commission (2019a), European Innovation Scoreboard Database, Luxembourg: Publication Office of the European Union.

- $\quad$ European Commission (2019b), 2019 SBA Fact Sheet. Romania, Internal market, industry, entrepreneurship and SMEs.

- European Commission (2020a), European Innovation Scoreboard 2020, Luxembourg: EC Directorate-General for Internal Market, Industry, Entrepreneurship and SMEs, Publications Office of the European Union.

- European Commission (2020b), Research and Innovation Observatory. 2020 Country-based indicators. [Online], [Retrieved August 11, 2020], https://rio.jrc.ec.europa.eu/stats/countrybased-indicators.

- European Economic and Social Committee (2017), Study on the assessment of the effectiveness of the EU SME policies 2007-2015, Visits and Publications Unit, Bruxelles.

- European Parliament (2010), The Lisbon Strategy 2000 - 2010. An analysis and evaluation of the methods used and results achieved. Final Report, European Parliament, Directorate General for Internal Policies, Bruxelles.

- $\quad$ Eurostat, 2019. Database. ICT usage în enterprises. [Online], [Retrieved March 3, 2020], https://ec.europa.eu/eurostat/data/datab ase 2020 .

- Feldman, M. and Audretsch, D. (1999), 'Science-Based Diversity, Specialization, Localized Competition and Innovation', European Economic Review, 43, 409-429.

- $\quad$ Gompers, P., Kovner, A., Lerner, J. and Scharfstein, D. (2010), 'Performance persistence in entrepreneurship', Journal of Financial Economics, 96 (1), 8-32.

- Haltiwanger, J., Lane, J. and Spletzer, J. (2007), 'Wages, productivity, and the dynamic interaction of businesses and workers', Labour Economics, Elsevier, 14 (3), 575-602.

- Hatos, A., Hatos, R., Badulescu, A. and Badulescu, D. (2015), 'Are Risk Attitudes and Individualism Predictors of Entrepreneurship in Romania?', Amfiteatru Economic, 17 (38), 148-161.

- Jovanovic, B. (1982), 'Selection and the Evolution of Industry', Econometrica, 50 (3), 649-670.

- Kok, J., Brouwer, P. and Fris, P. (2007), On the relationship between firm age and productivity growth, Scales Research Reports H200617, EIM Business and Policy Research.

- $\quad$ Kritikos, A. (2014), Entrepreneurs and their impact on jobs and economic growth, IZA World of Labor.

- Porter, M. (1990), The Competitive Advantage of Nations. Free Press, New York.

- PwC (2019), Central and Eastern Europe Private Business Survey 2019. [Online], [Retrieved August 3, 2020], www.pwc.com/epbs2019.

- $\quad$ Rad (Herțe), A D. (2020), IMM-urile și start-up-urile în economia contemporană: politici de sprijin și efectele acestora/ SMEs and start-ups in the contemporary economy: support policies and their effects, $\mathrm{PhD}$ Thesis, defended at University of Oradea, Romania, November 27th, 2020.

- Rodríguez-Pose, A. (2010), Do institutions matter for regional development?, Working Paper in Economics and Social Sciences No. 2, IMDEA Social Sciences, Madrid.

- Saxenien, A. (1994), Regional Advantage. Harvard University Press, Cambridge, MA.

- $\quad$ Shane, S. (2008), Why encouraging more people to become entrepreneurs is bad 
public policy, The Weatherhead School of Management, Case Western Reserve University, USA: World Entrepreneurship Forum.

- Thornhill, S. (2006), 'Knowledge, innovation and firm performance in high- and low-technology regimes', Journal of Business Venturing, 21 (5), 687-703.

- World Economic Forum (2019), The Global Competitiveness Report 2019, World Economic Forum, Geneva, Switzerland. 